\title{
Identification and characterization of Pseudomonas fluorescens strains effective against Xanthomonas oryzae pv. oryzae causing bacterial blight of rice in Punjab, India
}

\author{
Mandeep Singh Hunjan*, Anjali Thakur and Pushpinder Paul Singh \\ Department of Plant Pathology, Punjab Agricultural University, Ludhiana-141004 (Punjab), INDIA \\ ${ }^{*}$ Corresponding author E-mail: mandeep.hunjan@pau.edu
}

Received: July 13, 2016; Revised received: January 9, 2017; Accepted: January 25, 2017

\begin{abstract}
For the control of bacterial blight of rice caused by Xanthomonas oryzae pv. oryzae, sixty four Pseudomonas fluorescens strains were recovered from rice and wheat rhizosphere. These strains were identified on the basis of internal transcribed spacer (ITS) region. It was observed that the strains showing fluorescence in the selective media showed the amplification of the targeted $P$. fluorescens specific ITS region. The strains were also characterized for the production of the antibiotic 2, 4-diacetylphloroglucinol (DAPG) using phID locus. The characteristic $750 \mathrm{bp}$ region was amplified in all the DAPG producing strains. These strains were evaluated against $X$. oryzae in vitro by dual culture method. The $P$. fluorescens strains found effective in vitro were further tested in field for their antagonistic potentiality and disease suppression ability. $P$. fluorescens strain number Pf-4-R showed maximum inhibition i.e. of $5.5 \mathrm{~mm}$ against the test pathogen $X$. oryzae pv. oryzae. Talc based powder formulation of the effective strain Pf-4-R used for field evaluation, showed that pre-inoculation foliar sprays were effective in controlling bacterial blight of rice with disease suppression efficiency ranging from 29.6 to 65.6 per cent in different treatments.
\end{abstract}

Keywords: Bacterial blight, phl, Pseudomonas fluorescens; Xanthomonas oryzae pv. oryzae

\section{INTRODUCTION}

India is a leading country having highest area under rice cultivation, however, the yield per unit area $(22.07$ $\mathrm{q} / \mathrm{ha}$ ) in the country is among the lowest in the world (http://faostat.fao.org). One of the major limiting factors for lower grain yields are the occurrence of a number of diseases and insect pests. Rice crop is attacked by more than 60 diseases around the world which cause 50-70 per cent loss in rice yield (Jeung et al., 2006). Bacterial blight disease, caused by Xanthomonas oryzae pv. oryzae is one of the oldest known disease with worldwide incidence reported from different parts of Asia, Northern Australia, Africa and USA (Ghasemiet et al., 2008). Bacterial blight disease reduces yields and yield stability and some management strategies, such as chemicals, are harmful to the environment and in the tropical monsoon climate of Asia; no truly effective bactericide is commercially available for its control (Ou, 1973; Lee et al., 2003). The Punjab state, which is a major contributor to central food pool of India produces about 11.24 million tonnes with productivity of approximately $6033 \mathrm{~kg} / \mathrm{ha}$ (Anonymous, 2011). In Punjab, although resistant varieties have effectively tackled this pathogen (Bharaj et al., 2006), but resistance in released commercial cultivars is often broken down by the new pathotypes of $X$. oryzae pv. oryzae (Lore et al., 2011).
Biological control, therefore, assumes special significance in being an eco-friendly, cost-effective alternative strategy for bacterial blight management. This can also be used in integration with other strategies to attain greater levels of protection and rice yields. Antagonistic bacteria are considered ideal biological control agents because they have rapid growth, easy to handle and by virtue of their aggressive colonization of the rhizosphere (Weller, 1983).

Pseudomonas spp. have been studied as biocontrol agent mainly because of their widespread distribution in the soil, their ability to colonize the rhizosphere of host plant and ability to produce a wide range of compounds inhibitory to a wide array of plant pathogens (Thomashow et al., 1995; Rodriguez and Pfender, 1997; Anjaiah et al., 1998; Rangarajan et al., 2003). It has been reported that $P$. fluorescens dominates the group of plant growth promoting rhizobacteria (PGPR) which constitutes about 2-5 per cent of the bacteria adapted to rhizosphere (Landa et al., 2003). Fluorescent pseudomonads are among the most effective rhizobacteria that control plant pathogens through various mechanisms such as producing siderophores inhibiting plant pathogens through competition for iron, producing antibiotics or chitinase and glucanases lysing microbial cells. In addition to disease management, the application of antagonists also enhances the growth and vigor of 
plant in terms of root length or tillering (Manav and Thind, 2002).

The present study focuses on the use of $P$. fluorescens strains that produce 2,4-diacetylphloroglucinol (DAPG) to suppress bacterial blight in rice. Among a variety of metabolites produced by antagonistic fluorescent pseudomonads, diacetyl phluouroglucinol (DAPG) is among the most studied for their role in biocontrol of plant pathogens (Dowling and O'Gara, 1994; Keel et al., 1996; Sharifi-Tehrani et al., 1998; Raaijmakers et al., 1999; Notz et al., 2001, Velusamy et al., 2006, Jambhulkar and Sharma, 2014). In this study, different strains of $P$. fluorescens were isolated from wheat and rice plots amended with different organic amendments in a long term experiment, were characterized and tested for their biocontrol potentiality in a separate experiment at a parallel experimental site.

\section{MATERIALS AND METHODS}

Bacterial strains and media: Soil samples were collected from rhizosphere of rice and wheat crops grown on soil amended with different organic amendments in a long term experiment. Pseudomonas spp. strains were isolated from the soil suspensions of these rhizosphere samples that were serially diluted and plated onto King's B agar medium (HiMedia Laboratories). Single colonies exhibiting bluish green fluorescence were picked and further purified on the $P$. fluorescens selective media, Pseudomonas $\mathrm{HiVeg}^{\mathrm{TM}}$ Agar (HiMedia Laboratories). The purified cultures were stored at $-20^{\circ} \mathrm{C}$ in silica gel containing vials. Bacterial strains were identified further by using specific primers with respect to $16 \mathrm{SrDNA}$ region using primer set 16SF (5'AGAGTTTGATCCTGGCTCAG-3'); 16SR (5'CTACGGCTACCTTGTTACGA-3'). The culture of Xanthomonas oryzae pv. oryzae, $\mathrm{PbXo-7}$ was provided by Rice Pathology Laboratory, Department of Plant Breeding and Genetics, Punjab Agricultural University, Ludhiana.

In vitro antibiosis: Screening of the bacterial antagonists to $X$. oryzae $p v$. oryzae was carried out in Bacteriology Laboratory, Department of Plant Pathology by dual culture method. The potent antagonistic bacterial strains were selected on the basis of their ability to produce a zone of inhibition around $X$. oryzae $p v$. oryzae growth. The culture of $P$. fluorescens was streaked at right angle to the streak of 24 hour old growth the $X$. oryzae pv. oryzae on both sides forming an ' $\mathrm{H}$ ' shape. The inhibition zones were measured after 48 hour of incubation. The dual culture method led to the identification of efficient antagonistic strains which were selected for further studies.

PCR-based screening for phl locus: Effective and non effective strains found after dual culture were further identified by PCR based method on the basis of presence of $p h l$ gene which characterizes the production of antibiotic compound 2,4- DAPG. Antagonistic fluorescent Pseudomonas strains were screened for DAPG production by a PCR-based method developed and described by Raaijmakers et al. (1997).

The oligonucleotide primer pair PhlD.3F and PhlD.3R listed in Table 1 was developed from sequences within the biosynthetic loci for phlD gene of $P$. fluorescens (GenBank accession no. AB125213.1). All the primer sequences were synthesized by Integrated DNA Technologies (Coralville, USA). PCR amplification was carried out in a $25-\mathrm{ml}$ reaction mixture that contained approximately $25 \mathrm{ng}$ of DNA $1 \mathrm{X}$ Green GoTaq Flexi Buffer (Promega Inc., USA), $200 \mathrm{mM}$ each dATP, dTTP, dGTP, and dCTP (Promega Inc., USA), 20 pmol of each primer, and 2.0 U of GoTaq DNA polymerase (Promega Inc., USA). PCR amplifications were performed in Eppendorf Mastercycler ProS. The PCR program consisted of an initial denaturation at $94^{\circ} \mathrm{C}$ for $2 \mathrm{~min}$ followed by 30 cycles of $94^{\circ} \mathrm{C}$ for $60 \mathrm{~s}, 67^{\circ} \mathrm{C}$ for $45 \mathrm{~s}$, and $72^{\circ} \mathrm{C}$ for $60 \mathrm{~s}$. The amplified products $(8 \mathrm{ml})$ were separated on a 1.0 per cent agarose gel in $0.5 \mathrm{X}$ TBE buffer at $75 \mathrm{~V}$ for $3 \mathrm{~h}$. The gel was stained with ethidium bromide for $30 \mathrm{~min}$ and the PCR products were visualized with a UV transilluminator (Syngene, UK).

HPTLC based quantification: $P$. fluorescens isolates showing the presence of phl gene were further evaluated by High Performance Thin Layer Chromatography (HPTLC) method. The bacterial culture broth was prepared on King's B medium on an incubator-shaker for 72 hours. The fermentation broth was then centrifuged at $3500 \mathrm{rpm}$ for five minutes in a centrifuge. The supernatant containing cell free metabolites was collected and acidified to $\mathrm{pH} 2.0$ with $1 \mathrm{~N} \mathrm{HCl}$ and extracted with equal volume of ethyl acetate. The compound is soluble in organic solvent ethyl acetate as it mobilizes from broth to the solvent layer which was collected and kept at $4^{0} \mathrm{C}$ for further process. Production of DAPG was further quantified in each of the antibiotic producing strain by the protocol as given by Kar et al. (2013). Each band was quantified in a single beam, single wavelength reflectance mode, and relative front was taken into consideration for confirmation of the test chemical.

Preparation of Talc formulation: $P$. fluorescens strain, Pf-4-R which was found to be effective under in vitro evaluation was used for preparation of powder formulation. About $600 \mathrm{ml}$ of the $72 \mathrm{hrs}$ old liquid culture of Pf-4-R containing approximately $9 \times 10^{8} \mathrm{cfu} /$ $\mathrm{ml}$, was added to $1 \mathrm{~kg}$ of talc powder. The broth was mixed well with talc under sterile conditions. The mixture was then dried under aseptic conditions. The dried inoculated granular talc was grounded to fine powder forming the final product. The formulated product was packed in polythene bags, sealed and stored at $4 \pm 2^{\circ} \mathrm{C}$. 
Table 1. List of primers used in the study.

\begin{tabular}{llll}
\hline & Sequence (5'->3') & Expected product length & Reference \\
\hline Phl2a & GAGGACGTCGAAGAC- & 750 & Raaijmakers et al. (1997) \\
& CACCA & & \\
Phl2b & ACCGCAGCATCGTG- & & \\
& TATGAG & This study \\
Phld.3F & CCG- & $746 \mathrm{bp}$ & \\
& GATGGTCGCCGTGACTC & & \\
& ACTCGCCCAC- & & \\
\hline
\end{tabular}

Table 2. Treatments with antagonist with different delivery modules used in the study.

\begin{tabular}{|c|c|}
\hline Seed Treatment (ST) & $\begin{array}{l}\text { Wet seeds of basmati rice cultivar Pusa } 1121 \text { treated with the powder } \\
\text { formulation at the rate of } 10 \mathrm{gm} / \mathrm{kg} \text { seed }\end{array}$ \\
\hline $\begin{array}{l}\text { Seed Treatment and Seedling } \\
\text { Root Dip (ST + RD) }\end{array}$ & $\begin{array}{l}\text { Seed treatment was given in the same manner as described in } \mathrm{T}_{1} \text {. Thirty day } \\
\text { old seedlings were uprooted and washed thoroughly. The roots were dipped } \\
\text { in suspension of antagonist formulation at the rate of } 10 \mathrm{gm} / \text { liter for } 12 \text { hours } \\
\text { prior to transplanting. }\end{array}$ \\
\hline $\begin{array}{l}\text { Pre-Inoculation Foliar Spray } \\
\text { (Pre-IFS) }\end{array}$ & $\begin{array}{l}\text { Forty five days after transplanting, the plots were sprayed with product } \\
\text { formulation at the rate of } 10 \mathrm{gm} / 1 \text { uniformly covering all the leaves. } \\
\text { Inoculation of pathogen was done after } 24 \mathrm{hrs}\end{array}$ \\
\hline $\begin{array}{l}\text { Post-Inoculation Foliar Spray } \\
\text { (Post-IFS) }\end{array}$ & $\begin{array}{l}\text { Forty five days after transplanting, the plots were sprayed with product } \\
\text { formulation at the rate of } 10 \mathrm{gm} / 1 \text { uniformly covering all the leaves. } \\
\text { Inoculation of pathogen was done } 24 \mathrm{hrs} \text { prior to spray. }\end{array}$ \\
\hline $\begin{array}{l}\text { Seed Treatment, Seedling Root } \\
\text { Dip and Pre-Inoculation Foliar } \\
\text { Spray (ST + RD + Pre-IFS) }\end{array}$ & As above, in $\mathrm{T}_{1}, \mathrm{~T}_{2}$ and $\mathrm{T}_{3}$ \\
\hline $\begin{array}{l}\text { Seed Treatment, Seedling Root } \\
\text { Dip and Post-Inoculation Foliar } \\
\text { Spray (ST }+ \text { RD + Post-IFS) }\end{array}$ & As above, in $\mathrm{T}_{1}, \mathrm{~T}_{2}$ and $\mathrm{T}_{4}$ \\
\hline Chemical Seed Treatment & $\begin{array}{l}\text { The wet seeds were treated with Emisan } 6 \text { and Streptocycline at the rate of } \\
5 \mathrm{~g} \text { and } 1 \mathrm{~g} / \mathrm{kg} \text { of seed respectively and were sown in nursery beds. Thirty } \\
\text { days old seedlings were transplanted in the plots without any treatment }\end{array}$ \\
\hline Untreated Control & Seed and seedlings treated with water only \\
\hline
\end{tabular}

In-vivo evaluation: The antagonistic strain, Pf-4-R was evaluated in the field during rice seasons of 2011, 2012 and 2013 in the experimental area of Department of Plant Pathology, Punjab Agricultural University, Ludhiana. The experiment was laid out in randomized block design with three replications for each treatment. Thirty days old seedling of basmati rice cultivar Pusa 1121 were transplanted using two seedlings per hill in a plot size of $2 \times 2 \mathrm{~m}^{2}$ and spacing of $15 \mathrm{~cm} \times 20 \mathrm{~cm}$ Agronomic practices recommended by the Punjab Agricultural University, Ludhiana were followed for raising the crop. The efficacy of the antagonists was evaluated by the treatment sets given in Table 2 .

Disease inoculation: The concentrations of $1 \times 10^{9}$ $\mathrm{CFU} / \mathrm{ml}$ of $X$. oryzae $\mathrm{pv}$. oryzae was clip inoculated (Kaufmann et al. 1973) after 45 days of transplanting. A focus of infection was created by clip inoculating two plants at the center of each plot. Then spread of disease was allowed on its own under natural conditions. The observations on disease intensity were recorded 30 days after inoculation. Sixteen plants around the focus in all directions were selected i.e. four plants in each direction. Leaves from each selected plant were categorized using 0-9 scale.

The disease severity was calculated using the following formula-

Disease severity, DS (\%) = Sum of individual scores $\times 100$ / (Total leaves observed $\times$ maximum score)

The per cent disease suppression efficiency was calculated using the formula:

Disease suppression efficiency $(\%)=(\mathrm{DS}$ of control DS of treated group) $\times 100 /$ DS of control

\section{RESULTS AND DISCUSSION}

Isolation of Pseudomonas fluorescens: Out of 64 samples collected from rice and wheat rhizosphere, $P$. fluorescens was isolated from as many samples; 
however their number differed due to the sampling experimental site. Among these strains, four strains $(P f-2-\mathrm{R}, P f-4-\mathrm{R}, P f-9-\mathrm{R}$ and $P f-31-\mathrm{R})$ isolated from rice crop and three strains ( $P f-43-\mathrm{W}, P f-48-\mathrm{W}$ and $P f$ $-64-W)$ from wheat crop formed dark bluish green colored colonies with good growth rates (Thakur et al., 2011). Out of these, the strain number $P f-4-\mathrm{R}$ and $P f$ 48 -W exhibited dark green colored colonies with maximum growth rate.

PCR based identification: The strains showing good growth and fluorescence characters were further identified by the $16 \mathrm{srDNA}$ region amplification. It was found that all the strains showed the amplification of the targeted ITS (Internal transcribed spacer) region of the DNA of 850 base pair (Fig. 1), specific for the $P$. fluorescens. So, it was confirmed that all the strains of bioagent showing fluorescent characteristics in the selective medium were of $P$. fluorescens.

Phl based molecular identification of DAPG producing strains: DNA for all the strains was isolated and amplified using phlD based primer sets. Perusal to Figure 2, amplification of typical 750 base pair band was observed in all the strains that produced bluish green colonies. However in one strain i.e. Pf-39 -W isolated from wheat rhizosphere which showed light yellow pigmentation of the media showed no amplification at this locus suggesting that this strain of $P$. fluorescens does not produce any DAPG. It is also evident from Table 3 that this strain showed no inhibition zone when co-cultured with $X$. oryzae pv. oryzae, however it showed moderate growth rate. Another set of primers which were designed in-house i.e. phld.3, showed approximately $700 \mathrm{bp}$ fragment along with another $200 \mathrm{bp}$ amplicons from both wheat and rice strains. However, wheat isolated showed a third amplicon of approximately 300bp suggesting diversity of phlD locus in $P$. fluorescens strains recovered from wheat rhizosphere (Fig. 3).

In vitro efficacy of $P$. fluorescens against $X$. oryzae pv. oryzae : All the strains of $P$. fluorescens recovered from wheat and rice rhizosphere were evaluated in vitro against $X$. oryzae pv. oryzae. The inhibition zones were measured for each strain. It is evident from Table 1 that out of 32 rice rhizosphere strains, 17 were inhibitory to pathogen. Among these 17 strains, eight strains formed inhibition zone of $1.5 \mathrm{~mm}$ to $3 \mathrm{~mm}$ and three strains showed inhibition zone of more than 3 mm. Strain number $P f$-4-R exhibited high colony growth rate and also showed maximum inhibition i.e. of $5.5 \mathrm{~mm}$. Similarly, out of 32 wheat rhizosphere

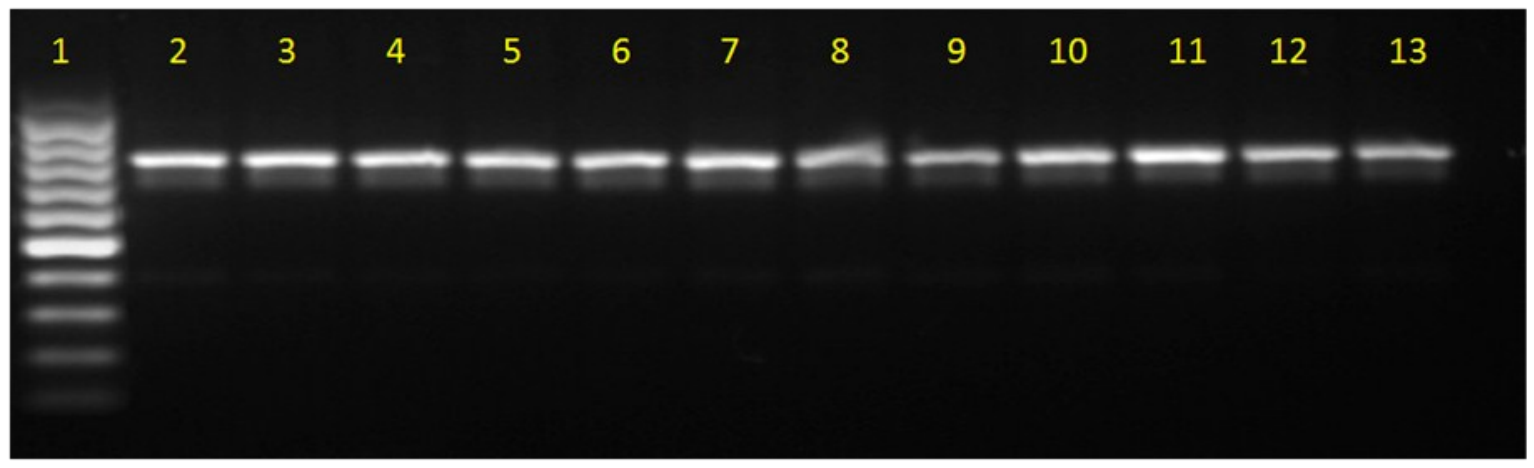

Fig. 1. The amplification products from twelve strains of $P$. fluorescens isolated from rice and wheat rhizosphere showing 850 bp amplicon specific to 16srDNA. Lane 1 contains 100bp DNA ladder (Promega Inc.), Lanes 2 to 7 contain Pf-2-R, Pf-4-R, Pf9-R, Pf-18-R, Pf-31-R, Pf-32-R; Lanes 8-13 contain amplified DNA from the strains Pf-34-W, Pf-39-W, Pf-48-W, Pf-49-W, Pf61-W, Pf-64-W.

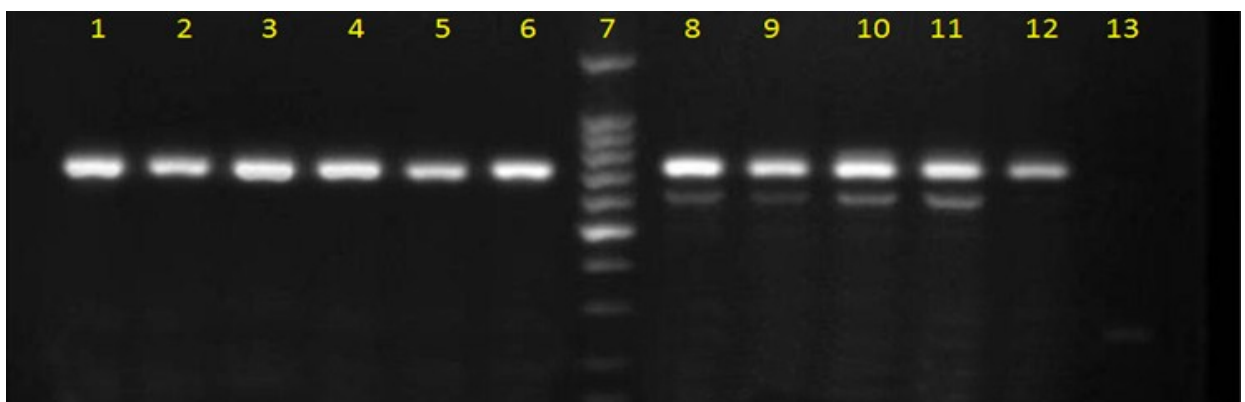

Fig. 2. The $750 \mathrm{bp}$ amplicon specific to phld gene amplified from six rice rhizosphere strains and six wheat rhizosphere strains with phlD primers. Lanes 1 to 6 contain amplified DNA from the strains $P f-2-R, P f-4-R, P f-9-R, P f-18-R, P f-31-R, P f-32-R$; Lane 7 contains 100bp DNA ladder (Promega Inc.); Lanes 8-12 contain amplified DNA from the strains Pf-34-W, Pf-48-W, Pf -49-W, Pf-61-W, Pf-64-W. No amplification in lane 13 (Pf-39-W). 
Table 3. In-vitro evaluation of potent strains of $P$. fluorescens against $X$. oryzae pv. oryzae by dual culture method.

\begin{tabular}{lcccc}
\hline Isolated from & Pf strains & Color & Growth & Inhibition zone (mm) \\
\hline Rice rhizophere & $P f-2-\mathrm{R}$ & Green & ++++ & 3.5 \\
& $P f-4-\mathrm{R}$ & Dark green & +++++ & 5.5 \\
$P f-9-\mathrm{R}$ & Green & Green & +++ & 3.0 \\
& $P f-18-\mathrm{R}$ & Dark green & ++++ & 3.0 \\
$P f-31-\mathrm{R}$ & Green & +++ & 3.0 \\
& $P f-32-\mathrm{R}$ & Green & +++ & 3.0 \\
Wheat rhizosphere & $P f-34-\mathrm{W}$ & Light Yellow & +++ & 0 \\
& $P f-39-\mathrm{W}$ & Green & +++ & 3.0 \\
$P f-48-\mathrm{W}$ & Green & +++ & 2.5 \\
& $P f-49-\mathrm{W}$ & Green & +++ & 3.0 \\
\hline
\end{tabular}

+++ Bacterial colonies appearing within 48 hours; with good growth

++++ Bacterial colonies appearing after 24 hours; with good growth

+++++ Bacterial colonies appearing within 24 hours; with very good growth

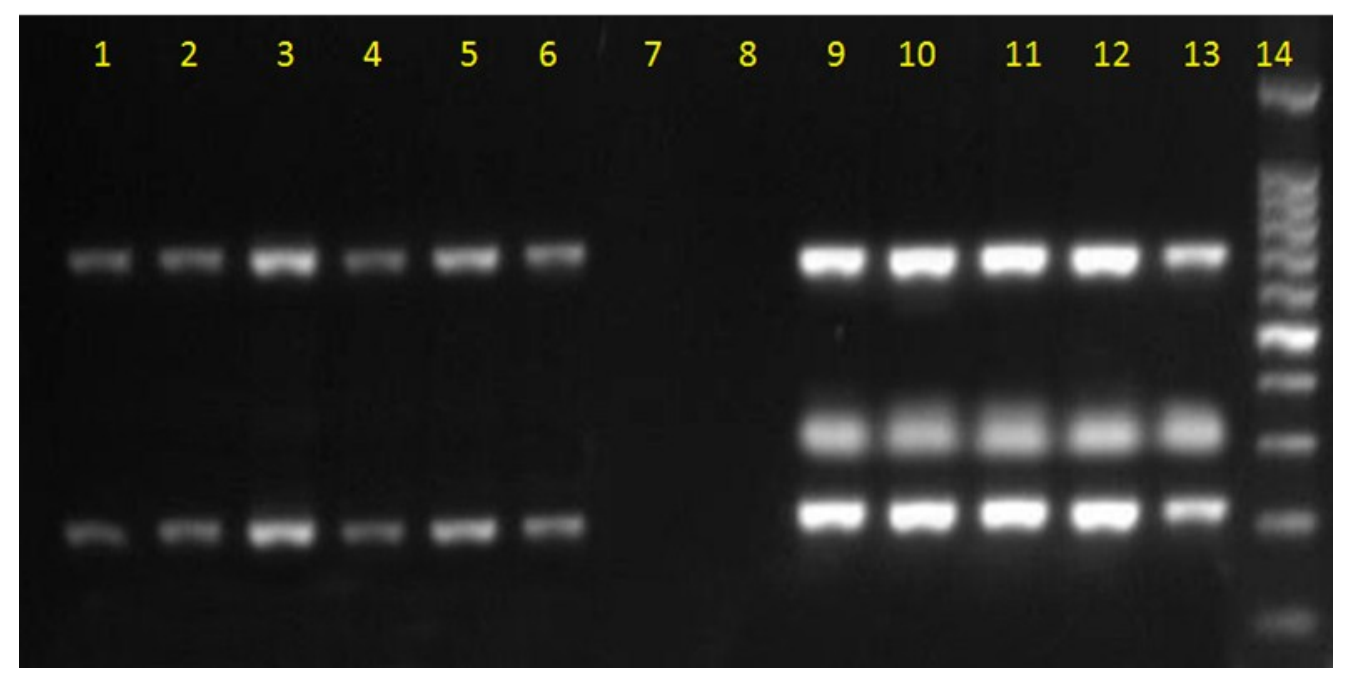

Fig. 3. The $\sim 750 \mathrm{bp}$ amplicon specific to phld gene amplified from six rice rhizosphere strains and six wheat rhizosphere strains with phlD. 3 primers. Lanes 1 to 6 contain amplified DNA from the strains Pf-2-R, Pf-4-R, Pf-9-R, Pf-18-R, Pf-31-R, Pf-32-R; Lane 7 is negative control; Lane 8 contains amplified DNA from Pf-39-W; Lanes 9-13 contain amplified DNA from the strains Pf-34-W, Pf-48-W, Pf-49-W, Pf-61-W, Pf-64-W; Lane14 contains 100bp DNA ladder (Promega Inc.).

strains, 13 were found to be inhibitory to the pathogen. Among these 13 strains, three formed inhibition zone of 1.0 to $2 \mathrm{~mm}$ and five strains showed inhibition zone in the range of $2 \mathrm{~mm}$ to $3 \mathrm{~mm}$. The strains $P f-34-\mathrm{W}, P f$ -48-W, $P f-61-\mathrm{W}$ and $P f-64-\mathrm{W}$ recovered from wheat rhizosphere also showed good colony growth and inhibition zone of $3 \mathrm{~mm}$.

From both the crops, eleven strains showing inhibition zone of more than $2.5 \mathrm{~mm}$ were selected and re-evaluated following same procedure. In the second experiment too, strain number $P f-4-\mathrm{R}$ isolated from rice rhizosphere showed the maximum inhibition zone of $5.5 \mathrm{~mm}$ with dark green colored colonies and maximum growth rate. The data is presented in Table 3 . The strains of the bioagent found effective under in vitro evaluation by dual culture and showing the presence of $p h l$ gene were further evaluated for the production of DAPG antibiotic by HPTLC method. It was found that all the effective strains ( $P f-2-\mathrm{R}, P f-4-\mathrm{R}$, $P f-18-\mathrm{R}, P f-48-\mathrm{W}$ and $P f-64-\mathrm{W})$ produced antibiotic 
Table 4. Evaluation of different delivery methods of $P$. fluorescens formulation against bacterial blight under field conditions.

\begin{tabular}{lcccc}
\hline Treatments & \multicolumn{3}{c}{ Mean disease Severity (\%) } \\
\cline { 2 - 5 } & $\mathbf{2 0 1 1}^{*}$ & $\mathbf{2 0 1 2}^{*}$ & $\mathbf{2 0 1 3 * *}$ & Mean \\
\hline Seed treatment & 23.3 & 26.4 & 18.2 & $22.6^{\mathrm{a}}$ \\
S T + R D & 20.9 & 21.2 & 17.1 & $19.7^{\mathrm{b}}$ \\
Pre-I F S & 16.6 & 10.1 & 12.6 & $13.1^{\mathrm{c}}$ \\
Post- I F S & 23.7 & 14.7 & 14.8 & $17.7^{\mathrm{d}}$ \\
ST + RD + Pre-IFS & 13.5 & 10.9 & 11.9 & $12.1^{\mathrm{c}}$ \\
ST + RD + Post-IF S & 20.3 & 18.2 & 13.2 & $17.2^{\mathrm{d}}$ \\
Chemical seed treatment & 27.9 & 24.1 & 20.2 & $23.9^{\mathrm{a}}$ \\
Untreated control & 30.2 & 28.7 & 19.7 & $26.4^{\mathrm{e}}$ \\
\hline & Years $<0.001$ & & \\
P>F $(0.01)$ & Treatments $<0.001$ & & \\
\end{tabular}

Mean figures followed by same letter do not differ significantly; * The disease severity data obtained in years 2011 and 2012 do not significantly differ from each other; **The disease severity data obtained in year 2013 differed significantly from disease severity data in 2011 and 2012 both.

DAPG in varying quantities. However, $P f-4-\mathrm{R}$ produced maximum amount of antibiotic (2113.7 AU), which was closely followed by strain Pf-64-W (2030.8 AU). However, other strains viz. Pf-48-W (1247.0 AU), $P f-2-\mathrm{R}(809.5$ AU) and $P f-18$-R (762.5 AU) produced significantly lesser amount of the DAPG. The results observed were in conformation with dual culture findings, as measure of inhibition zone produced was found to be directly correlated with the amount of antibiotic produced. Based on these results, the strain $P f-4-R$ was selected for evaluation under field conditions.

In-vivo evaluation: Significant reduction in disease severity was observed in the treatments with pre-inoculation foliar spray (Fig. 4), either alone $(50.4 \%)$ or in combination with seed treatment and seedling root dip treatment $(54.2 \%)$ over the control plots. As is evident from Table 4, highest mean disease severity was observed in the untreated control treatment (DS, 36.4\%) followed by chemical control (DS, 23.9\%). Similarly, post-inoculation foliar sprays were also effective in managing bacterial blight disease using Pf-4-R formulation (Table 4). In this three year experiment, results were consistent for the first two experimental seasons and did not differ significantly, however we obtained significant variation during the third year. The mean disease severity values for 2011 and 2012 seasons were 22.1 and 19.3 per cent respectively while during the third year, it was observed to be 16 per cent. It may be attributed to the prevailing relatively dry conditions during the plant inoculations and the subsequent pathogenesis period. Initial seed priming with $P f-4-\mathrm{R}$ as seed treatment and seedling root dip treatment improved the overall plant vigour, but that did not contribute much towards reducing disease severity at later stages of crop growth. However, with pre-inoculation foliar sprays of $P f-4-\mathrm{R}$ formulations (alone or in combination), significant reduction in disease development was noticed (Fig. 4). It was also observed that following the pre-inoculation foliar spray treatment, the lesion lengths on the clipped leaves developed partially. So, under field conditions pre-inoculation foliar spray treatment proves to be effective treatment in disease control showing maximum disease suppression efficiency followed by post-inoculation foliar spray. Soil rhizobacteria are often difficult to identify and characterize on simple isolation media or on the basis of their colony structure and morphology. However, molecular tools have provided markers for accurate identification of these bacteria and in the present study $P$. fluorescens isolated from the rhizosphere of rice and wheat were identified on the basis of molecular markers based on ITS (Internal transcribed spacer) region. Molecular identification was performed by using the primer set 16SF-16SR and it was observed that all the strains showed the amplification of the targeted ITS region of the DNA of 850 base pair, specific for the $P$. fluorescens. It was confirmed that all the strains of bioagent showing fluorescent characteristics in the selective medium were $P$. fluorescens.

The findings were in conformation with Scarpellini et al. (2004), who also used the polymerase chain reaction to amplify a specific portion of the $16 \mathrm{~S}$ gene, allowing the recognition of $P$. fluorescens from other group of Pseudomonas. Eleven strains in this study were found to be effective against $X$. oryzae pv. ory$z a e$. Native strains of rhizobacteria $P$. fluorescens have been reported for antagonist activity against $X$. oryzae pv. oryzae by Sakthivel et al. (1988) and Ramanamma et al. (1994) who also reported formation of large inhibition zones by $P$. fluorescens against $X$. oryzae pv. oryzae in synthetic medium. Similarly, Battu and Reddy (2009) isolated 20 P. fluorescens 


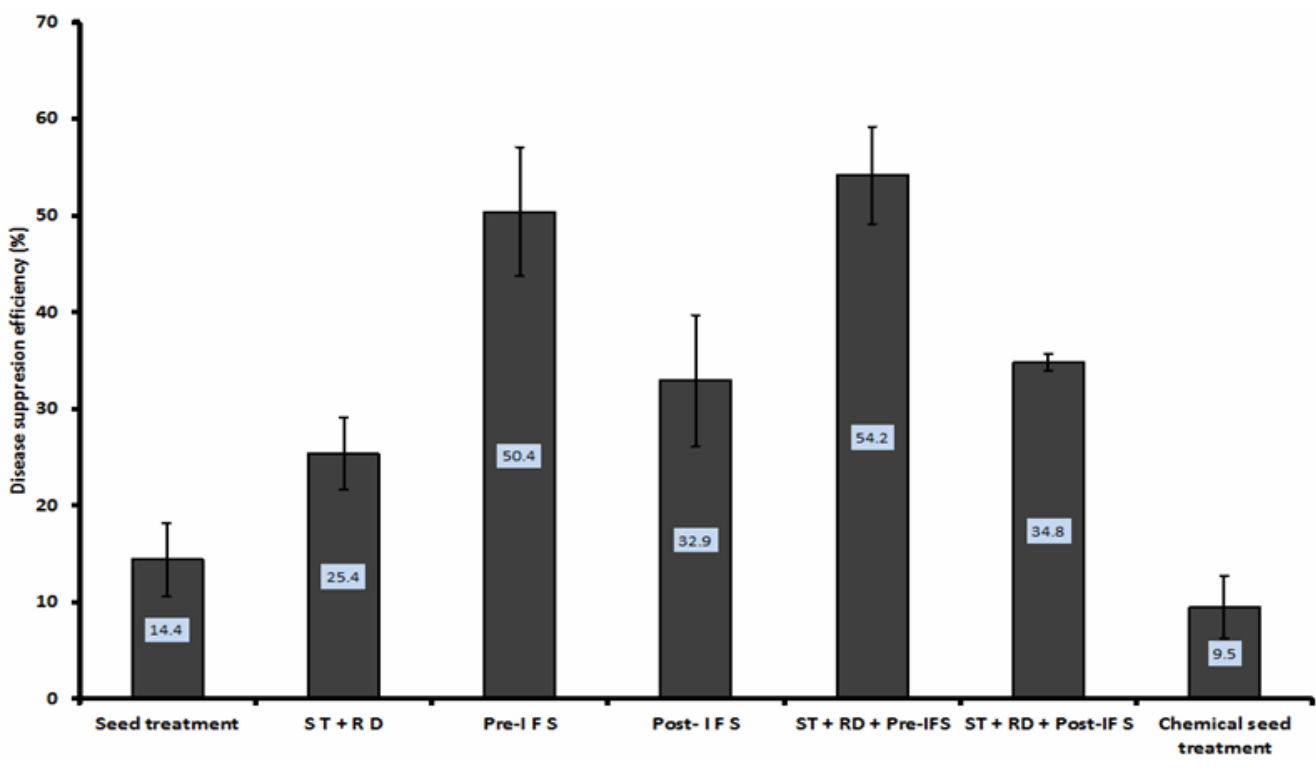

Fig. 4. Disease suppression efficiency of $P$. fluorescens strain Pf-4R against bacterial blight of rice using different delivery methods.

strains from rice growing soil samples and characterized them by dual culture test against rice fungal pathogens. The potent strains were further characterized by molecular markers based on phl gene. They concluded that antagonism of the bioagent is dependent on the presence $P h l$ gene which signifies the production of antibiotic like substance, DAPG inhibitory to phytopathogens as evident from our studies as well. Root-associated fluorescent Pseudomonas spp. producing the antibiotic 2, 4-diacetylphloroglucinol ( $P h l$ gene) is a key component of the natural biological control. Velusamy et al. (2004) characterized plant associated bacteria from different states of India and provided positive conformation to the role of 2, 4Diacetylphloroglucinol (DAPG) as an antibacterial compound in suppression of bacterial blight of rice. It was also noted in our studies that strain $P f-4-R$, that produces maximum DAPG, also showed maximum antagonism towards $X$. oryzae pv. oryzae. Raaijmakers et al. (1999) also reported that fluorescent Pseudomonas spp. that have $\mathrm{Phl}$ gene play an important role in the natural suppressiveness of these soils to take-all disease of wheat.

In the course of isolations of fluorescent pseudomonads, the strains showing fluorescent colored colonies with good growth rates were selected. The P. fluorescens strains show wide spectrum of inhibitory activity, mostly due to production of fluorescent siderophores. Santhi et al. (1987) had reported the role of fluorescent pigments in antagonism exhibited by $P$. fluorescens. Similarly in this study also, eleven strains were found to highly inhibitory to the pathogen and produce inhibition zones of more than $2.5 \mathrm{~mm}$. Though some researchers have found no correlation between in-vitro antagonism exhibited by the bacteria and their ability to suppress disease under greenhouse or field conditions (Papavizas and Lewis, 1983), there are other reports suggesting it is possible to identify efficient biocontrol agent based on their inhibition in dual culture method in the laboratory (Gnanamanickam and Mew, 1992; Mew and Rosales, 1986). To control various plant disease in other crops, fluorescent Pseudomonads have been routinely employed as seed treatment (Niranjana et al., 2009), seedling root dip (Verma, 2009) or soil drenching (Jayalakshmi et al., 2010). These delivery systems have been used individually or in combinations to achieve different levels of disease control. In this study, it was found that strain which showed in-vitro antibiosis could also suppress disease effectively in the field experiments. Pre-inoculation foliar sprays either alone or in combination of seed treatment and seedling root dip provided maximum disease control. Similar results were reported by other workers also (Rishnamurthy and Gnanamanickam, 1998), wherein they have found that bioagent when applied as seed treatment + root dip + two foliar spray gave better disease control of other rice diseases such as sheath blight.

\section{Conclusion}

It is concluded from the present studies that different strains of Pseudomonas fluorescens can be very effectively pre-screened prior to in vitro testing against Xanthomonas oryzae pv. oryzae using molecular screens; particularly amplifying the DAPG producing loci. It is further concluded that the Pf-4 strain selected on the above said basis when used as pre inoculation foliar spray as antagonist to $X$. oryzae $p v$. oryzae suppressed the bacterial blight disease effectively under field conditions and can be incorporated in integrated disease management practices. 


\section{REFERENCES}

Anjaiah, V., Koedam, N., Thompson, N.B., Loper, J.E., Hofte, M., Tambong, J.T. and Cornelis, P. (1998). Involvement of phenazines and anthranilate in the antagonism of $P$. auregenosa PNA1 and Tn5 derivatives towards Fusarium sp. and Pythium sp. Molecular Plant Microbe Interactions 11:847-854

Anonymous, (2011). Package of Practices for Kharif crops, Punjab Agricultural University, Ludhiana, Pp 1-17.

Battu, P.R. and Reddy, M.S. (2009). Isolation of secondary metabolites from Pseudomonas fluorescens and its characterization. Asian Journal of Research in Chemistry 2: 26-29

Bharaj, T.S., Singh, N., Kaur, R., Bhullar, M.S. (2006). Genetic enhancement for yielding ability and bacterial blight resistance in rice (Abstract). Proc 2nd International Rice Congress, New Delhi, October 9-13, 2006, pp 296.

Dowling, D.N. and O'Gara, F. (1994). Metabolites of Pseudomonas involved in the biocontrol of plant disease. Trends in Biotechnology 12: 133-141

Ghasemiet, E., Kazempour, M.K. and Padah, F. (2008). Isolation and identification of Xanthomonas oryzae pv. oryzae the causal agent of bacterial blight of rice in Japan. Journal of Plant Protection 48: 53-62

Gnanamanickam, S.S. and Mew, T.W. (1992). Biological control of blast disease of rice (Oryza sativa L.) with antagonistic bacteria and its mediation with a Pseudomonas antibiotic. Annals of Phytopathological Society of Japan 58: 380-385

Jambhulkar, P.P. and Sharma, P. (2014). Development of bioformulation and delivery system of Pseudomonas fluorescens against bacterial leaf blight of rice (Xanthomonas oryzae pv. oryzae). J. Environ Biol. 35:843-849

Jayalakshmi, C., Madhiazhagan K. and Rettinassababady C. (2010). Effect of different methods of application of Pseudomonas fluorescens against bacterial leaf blight under direct sown rice. J. Biopest. 3:487- 488

Jeung, J.U., Heu, S.G., Shin, M.S., Cruz, C.M. and Jena, K.K. (2006). Dynamics of Xanthomonas oryzae pv oryzae population in Korea and their relationship to known bacterial blight resistance genes. Phytopathology 96: $865-75$

Kar, A., Mandal, K. and Singh, B. (2013). Environmental fate of chlorantraniliprole residues on cauliflower using QuEChERS technique. Environmental Monitoring and Assessment 185: 1255-1263

Kaufmann, H.E., Reddy, A.P.K., Hseih, S.P.Y. and Merca, S.S. (1973). An improved technique for evaluating resistance of rice varieties to Xanthomonas oryzae. Plant Disease Reporter 57: 537-541

Keel, C., Weller, D.M., Natsch, A., Defago, G., Cook, R.J. and Thomashow, L.S. (1996). Conservation of the 2,4diacetylphloroglucinol biosynthesis locus among fluorescent Pseudomonas strains from diverse geographic locations. Applied and Environmental Microbiology 62: 552-563

Landa, B.B., Mavrodi, D.M., Thomashow, L.S. and Weller, D.M. (2003). Interaction between strains of 2,4Diacetylphloroglucinol producing Pseudomonas fluorescens in the rhizosphere of wheat. Phytopathology 93: 982-994
Lee, K.S., Rasabandith, S., Angeles, E.R. and Khush, G.S. (2003). Inheritance of resistance to bacterial blight in 21 cultivars of rice. Phytopathology 93: 147-52

Lore, J.S., Vikal, Y., Hunjan, M.S., Goel, R.K., Bharaj, T.S. and Raina, G.L. (2011). Genotypic and pathotypic diversity of Xanthomonas oryzae pv. oryzae, the cause of bacterial blight of rice in Punjab state of India. Journal of Phytopathology 159: 479-87

Manav, M. and Thind, B.S. (2002). Management of bacterial blight of rice with bioagents. Plant Disease Research 17: $21-28$

Mew, T.W. and Rosales, A.M. (1986). Bacterization of rice plants for control of sheath blight caused by Rhizoctonia solani. Phytopathology 76: 1260-1264

Niranjana, S.R., Lalitha, S. and Hariprasad P. (2009). Mass multiplication and formulations of biocontrol agents for use against fusarium wilt of pigeonpea through seed treatment. Int. J. Pest Mgt. 55: 317-324

Notz, R., Maurhofer, M., Schnider-Keel, U., Duffy, B., Haas, D. and Defago, G. (2001). Biotic factors affecting expression of the 2,4-diacetylphloroglucinol biosynthesis gene phlA in Pseudomonas fluorescens strain CHAO in the rhizosphere. Phytopathology 91: 873-881

Ou, S.H. (1973). A Handbook of Rice Diseases in the Tropics. Pp 58. Los Baños: International Rice Research Institute.

Papavizas, G.C. and Lewis, J.A. (1983). Physiological biocontrol characteristics of stable mutants of Trichoderma viride resistance to MBC fungicides. Phytopathology, 73: 407-411

Raaijmakers, J.M., Bonsall, R.F. and Weller, D.M. (1999). Effect of population density of Pseudomonas fluorescens on production of 2,4-diacetylphloroglucinol in the rhizosphere of wheat. Phytopathology 89: 470 475

Raaijmakers, J.M., Weller, D.M. and Thomashow, L.S. (1997). Frequency of antibiotic-producing Pseudomonas spp. in natural environments. Applied and Environmental Microbiology 63: 881-887

Ramanamma, C., Bharathi, G. and Sreeramula, A. (1994). Paddy rhizosphere bacterium inhibiting rice plant pathogens. Journal of Ecotoxicology and Environmental Monitoring 4: 65-69

Rangarajan, S., Saleenal, L.M., Vasudevan, P. and Nair, S. (2003). Biological suppression of rice diseases by Pseudomonas spp. under saline soil conditions. Plant and Soil 251: 73-82

Rishnamurthy, S. and Gnanamanickam, S.S. (1998) Biocontrol of rice sheath blight with formulated Pseudomonas putida. Indian Phytopathology 51:233-36

Rodriguez, F. and Pfender, W.F. (1997). Antibiosis and antagonism of Sclerotinia homo eocarpa and Drechslera poae by Pseudomonas fluorescens PF-5 in vitro and in planta. Phytopathology 87: 614-621

Sakthivel, N., Swamani, E., Anuratha, C.S., Savithiry, S. and Gnanamanickam, S.S. (1988). Advances in research on plant pathogenic bacteria. In S.S. Gnanamanickam and A.J. Mahadevar (Eds.) Proceedings of National Symposium on Phytobacteriology held at the University of Madras, Madras, India, March 14-15, 1986 (pp. 213 220) New Delhi: Today and Tomorrow's Printers and Publishers.

Santhi, D.P., Unnamalai, N. and Gnanamanickam, S.S. 
(1987). Epiphytic association of Erwinia herbicola with rice leaves infected by Xanthomonas oryzae pv. oryzae and its interaction with pathogen. Indian Phytopatholog 40: $327-32$

Scarpellini, M., Franzetti, L. and Galli, A. (2004). Development of PCR assay to identify Pseudomonas fluorescens and its biotype. FEMS Microbiology Letters 236:257-260

Sharifi-Tehrani, A., Zala, M., Natsch, A., Moenne-Loccoz, Y. and Defago, G. (1998). Biocontrol of soil-borne fungal plant diseases by 2,4-diacetylphloroglucinol producing fluorescent pseudomonads with different restriction profiles of amplified 16S rDNA. European Journal of Plant Pathology 104: 631-643

Thakur, A., Singh, P.P. and Hunjan, M.S. (2011). Rhizosphere competence of $P f-4-R$, a strain of Pseudomonas fluorescens colonizing rice roots. Plant Disease Research 26: 127-131

Thomashow, L.S., and Weller, D.M. (1995). Current concepts in the use of introduced bacteria for biological disease control: mechanisms and antifungal metabolites. In G. Stacey and N. Keen (Eds.) Plant-microbe interactions, Vol. 1 (pp. 187-235) New York: Chapman $\&$ Hall.

Velusamy, P., Defago, G., Thomashow, L. and Gnanamanickam, S.S. (2004). Role of 2,4-diacetylphloroglucinol for plant disease control: its importance to rice bacterial blight suppression in India. In L.V. Gangawane and C.D. Mayee (Eds.) Biotechnological approach for the integrated management of crop diseases (pp. 182-191) New Delhi: Daya Publishing House.

Velusamy, P., Immanuel, J.E., Gnanamanickam, S.S. and Thomashow, L. (2006). Biological control of rice bacterial blight by plant-associated bacteria producing 2,4-diacetylphloroglucinol. Can J Microbiol. 52:56-65.

Verma, K.K. (2009). Management of Meloidogyne javanica by bacterial antagonist Pseudomonas fluorescens as seedling root dip in tomato. Indian J. Nematol. 39: 207210

Weller, D.M. (1983). Colonization of wheat roots by a fluorescent pseudomonad suppressive to take-all. Phytopathology 73:1548-1553 